International Journal of Engineering \& Technology, $7(4.34)(2018) 137-139$
International Journal of Engineering \& Technology
SPC
Website: www.sciencepubco.com/index.php/IJET
Research paper

\title{
Social Capital Impact on Quality of Life of Low-Income Population Group
}

\author{
Aziz Amin*, Ahmad Puad Mat Som, Zainul Zolkifeli \\ Faculty of Applied Social Science, Universiti Sultan Zainal Abidin, Gong Badak Campus, 21300 Kuala Nerus, Terengganu, Malaysia \\ *Corresponding author E-mail: wanazizmn@unisza.edu.my
}

\begin{abstract}
Efforts to improve the quality of life are often the goals of development programs in every country, Malaysia is no exception. Various policies and programs have been conducted to ensure the quality of life of the community to be at a high level. Each country has its own resources in the form of raw materials, investments, labor and so on. Social capital is one of the resources in a country. Thus, this study is conducted to identify the impact of social capital on respondents' quality of life. This study focuses on the low income group of bottom 40 per cent of the population, so-called B40 as respondents. Surveys were conducted to 100 household heads in Kuala Terengganu, Terengganu, Malaysia. SPSS software has been used to analyze the data that was collected. The findings show that social capital is able to influence the respondents' quality of life. Therefore, each program or policy framework should be in line with the needs of social capital constructs to impact quality of life of the society.
\end{abstract}

Keywords: Quality of Life; Social Capital; Low Income Group.

\section{Introduction}

Social capital and how to gauge it are as yet an energy for government officials and scholastics [1]. As of late, sociologists and financial analysts have conceded that physical capital is not the main capital requirement. Many scholars propose that human capital, regular capital, social capital and social capital likewise have an essential part in human social life [2]. Thus, social capital can be portrayed as a reciprocal idea of network life. As indicated by [3], this relationship and correspondence in various structures go about as a security with the goal that components in the public eye can be coordinated and worked as social participation. The objective of common improvement at the neighborhood, national and global levels is likewise to advance personal satisfaction. A portion of these components are found to affect the nature of our association with other individuals, gatherings and formal and casual areas communicated as social capital. In [4] utilizes objective accomplishment, conduct, status and solace as a pointer of the prosperity of life. In [5] starting in 2016, 36,959 families in the locale of Kuala Terengganu have a place with the lower wage amass B40. This sum speaks to $34.1 \%$ of the whole B40 bunch over the province of Terengganu. The B40 amass salary confine for the territory of Terengganu is RM (Ringgit Malaysia) 4,070.

\section{Literature Review}

Social capital can be said to be very new in principle and research as it was just presented in the 1980 s by a few sociologists, including Bourdieu, Coleman and Lin who openly investigated the idea in detail contends that previously, financial analysts and strategy producers stressed the aggregation of physical and human capital as a method for accomplishing formative destinations, for example, raising pay, wellbeing and instruction. Notwithstanding, overlook- ing social capital may bring about inability to accomplish maximum capacity of improvement. The discoveries demonstrate that social capital assumes a critical part in enhancing the personal satisfaction. Interest in social capital is relied upon to enhance expectations for everyday comforts, as well as to enhance the personal satisfaction. In [6] attempt to consider the connection between social capital and the results of the poor by the poor to diminish their destitution and social prohibition in Mexico and Focal America. In [7] utilizes a quantitative approach and investigation in its examination to survey social capital connections on financial improvement. The discoveries demonstrate that there is a relationship between monetary advancement and social capital. In [8] directed an investigation on the significance of social capital. The outcome demonstrates that social capital assumes an imperative part in decreasing neediness rates. In [9] examines a few things. Among them are the idea of social capital, social capital status, how it associates with different factors in worldwide advancement, and how it will add to financial development and a decrease in future neediness rates.

In [10] said that living prosperity is basically to deliver the issue and to enhance the personal satisfaction of an individual in a sheltered, sound and agreeable life both physically, socially and mentally. In [11] in his investigation isolates the prosperity into two classes of value, specifically target personal satisfaction and subjective personal satisfaction. As indicated by him, the personal satisfaction is a target of life that can be delighted in by people and can be seen remotely as salary, lodging, wellbeing and instruction. The subjective personal satisfaction is the fulfilment and pleasure in the person that he has a craving for being glad and appreciative for having a great job, effective youngsters and a cheerful family. He clarified that the prosperity of life is a nature of subjective life in light of the fact that the prosperity is the finish of the fulfilment and decency of man. In [12] clarifies the idea of living prosperity or personal satisfaction is not just estimated by material esteem alone, for example, home proprietorship, vehicle, 
abnormal state of training, yet it likewise incorporates nonmaterial perspectives, for example, love and a feeling of empathy. In the present mechanical progression, the general public is likewise less associated up close and personal, the part of social capital is progressively clear and essential as it is additionally part of virtual capital [13]. Studies directed by specialists in different social fields in a few nations have discovered that social capital assumes a vital part in making financial progress [14]. This investigation recommends that social capital assumes a part in setting up collaboration amongst networks and money related foundations that is required to help the advancement of open endeavours. This social capital approach is another option to financial advancement techniques of monetarily wasteful local gatherings typically bolstered by reserves got from government-helped venture help. In [15] contends that in different parts of the economy, social orders with social capital will profit more than the individuals who do not have it. As indicated by him, social capital is basically a sentiment of sensitivity from a man or gathering of individuals to someone else or gathering. This sentiment of sensitivity can be wonderment, love, friendship, compassion, gratefulness, duty, or trust in a man or gathering of individuals.

Hence, based on the highlighted work, this study has proposed a conceptual framework (Figure 1) to identify the impact of social capital on the quality of life. Six elements have been included in the social capital variables. These elements are networks and communications; trust; values, norms and habits; social rules; ability or capability of self and religious needs.

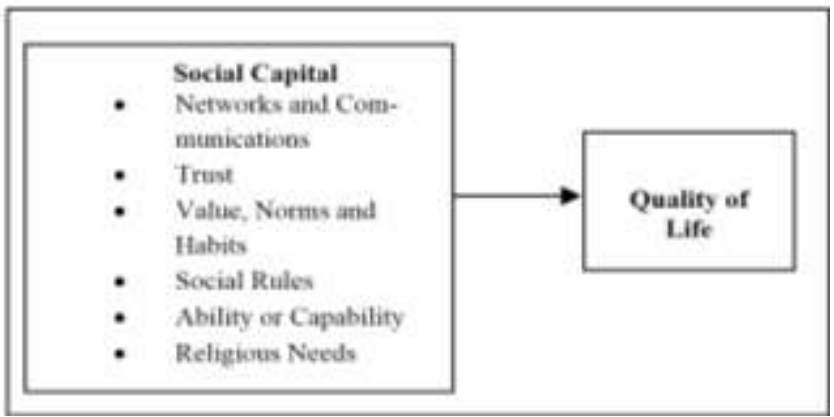

Fig. 1: Conceptual framework

\section{Methodology}

Based on literature review, this study has identified and used several variables which have been tested for reliability (refer to Table 1). The study was quantitative and was conducted on the heads of the household who lived in Kuala Terengganu. Questionnaire items were related to social capital elements and quality of life. This study applied stratified random sampling techniques based on the total household income in the B40 group. A total of 100 presample studies were selected from the B40 household group in Kuala Terengganu, and data were processed and analysed using the Statistical Package for Social Science (SPSS). Among the analyses performed were the reliability test and the inference analysis.

Table 1: Results of Reliability Test Analysis

\begin{tabular}{|c|c|c|}
\hline Item & Number of Item & Cronbach's Alpha \\
\hline Quality of Life & 35 & 0.897 \\
Social Capital & 61 & 0.849 \\
\hline
\end{tabular}

Based on Table 1, the values of Cronbach's Alpha for items of quality of life and social capital, were 0.897 and 0.849 respectively. All of the above Cronbach's Alpha values exceeded 0.6 means the above items are suitable for use and acceptable as measurement.

\section{Results and Discussion}

\subsection{Demographic Profile}

The total number of respondents of this study was 100 people. Based on Table 2 below, $87 \%$ were male and $13 \%$ were female. $59 \%$ of respondents aged between 36 to 50 years old and $95 \%$ were married. In addition, education level showed that $62 \%$ of respondents had education level at SPM level and 28\% had education at STPM / Diploma level. In terms of employment, $38 \%$ of respondents were self-employed while $36 \%$ of respondents were working in private sector. $28 \%$ of respondents had income from RM1001 to RM2000 per month while 56\% others had income of RM2001 to RM3000 per month.

Table 2: Respondents' Demographic Profiles

\begin{tabular}{|c|c|c|c|}
\hline $\begin{array}{c}\text { Demographics } \\
\text { Profile }\end{array}$ & Category & Frequency & Percentage \\
\hline Age & 21 to 35 & 35 & 35.0 \\
& 36 to 50 & 59 & 59.0 \\
& 51 to 65 & 6 & 6.0 \\
\hline Gender & Male & 87 & 87.0 \\
& Female & 13 & 13.0 \\
\hline Marital & Single & 4 & 4.0 \\
status & Married & 95 & 95.0 \\
& Widowed & 1 & 1.0 \\
\hline Level & SRP/PMR & 2 & 2.0 \\
of & SPM & 62 & 62.0 \\
education & STPM/Diploma & 28 & 28.0 \\
& Degree and above & 8 & 8.0 \\
\hline Profession & Government servants & 25 & 25.0 \\
& Private Sector & 36 & 36.0 \\
& Self-employed & 38 & 38.0 \\
& Unemployed & 1 & 1.0 \\
\hline Monthly & RM0001-RM1000 & 4 & 4.0 \\
income & RM1001-RM2000 & 28 & 28.0 \\
& RM2001-RM3000 & 56 & 56.0 \\
& RM3001-RM4000 & 12 & 12.0 \\
\hline \multicolumn{3}{|c}{} & \multicolumn{2}{c}{} \\
\hline
\end{tabular}

Min capability of the social capital index, as shown in Table 3, was the scale of measurement for this study with a value from 1 to 5 , representing the value of 1 indicating a low measurement scale while value 5 indicates a high measurement scale.

Table 3: Min Quality of Life and Social Capital

\begin{tabular}{|c|c|c|c|c|}
\hline Variables & Minimum & Maximum & Min & SD \\
\hline Quality of Life & 2.49 & 4.54 & 3.914 & 0.304 \\
Mental Health & 3.00 & 4.60 & 4.222 & 0.286 \\
Network and Communica- & 3.00 & 4.45 & 3.593 & 0.203 \\
tions & 2.80 & 4.50 & 4.001 & 0.444 \\
Trust & 3.20 & 5.00 & 4.251 & 0.337 \\
Value, Norms and Habits & 3.20 & 4.20 & 3.858 & 0.236 \\
Social rules & 2.90 & 4.50 & 4.252 & 0.318 \\
Capability or Ability & 3.00 & 5.00 & 4.343 & 0.269 \\
Religious Needs & & & & \\
\hline
\end{tabular}

Based on Table 3, all variables of life quality and dimensions of social capital, network and communication; trust; values, norms and habits; social rules; capability or self-esteem and religious needs indicate a min greater than 3 . This indicates the level of quality of life, mental health and social capital is high because the median scale for this scale is 3 . If the value is greater than 3 , it is considered as good as it is closer to the value 5. On the other hand, if the mean value of the score is lower than 3 , the variable's level is considered low because it is approaching the minimum value 1 . The scale of this measurement refers to the study conducted by [16]. Hence, all variables of the B40 group scored highly.

The findings of regression analysis show the effects of independent variables that are social capital factors on respondents' quality of life. Based on the correlation analysis, only two factors showed insignificant value, network and communication and trust. Only factors with significant correlation value can be measured by the effects of regression analysis. 
Table 4: Model Summary

\begin{tabular}{|c|c|c|c|}
\hline $\mathrm{R}$ & R Square & Adjusted R & Std. Error of The Estimate \\
\hline 0.393 & 0.154 & 0.137 & 0.28226 \\
\hline
\end{tabular}

Relapse research demonstrates that $\mathrm{R}^{2}$ is 0.154 (refer to Table 4). This demonstrates the impact of social capital factors on the personal satisfaction of the respondents is $15.4 \%$. As indicated by [17-18], the relapse result is thought to be great in spite of the fact that the $\mathrm{R}^{2}$ esteem is under 20 percent, since this esteem is basically a manual for the flawlessness of the relapse demonstration. Notwithstanding the social capital variables examined, there are likewise different components that may influence the nature of respondents' lives.

Table 5: ANOVA

\begin{tabular}{|c|c|c|c|c|c|}
\hline Model & $\begin{array}{c}\text { Sum of } \\
\text { Squares }\end{array}$ & df & $\begin{array}{c}\text { Mean } \\
\text { Square }\end{array}$ & F & Sig. \\
\hline Regression & 1.408 & 2 & 0.704 & 8.836 & 0.000 \\
\hline Residual & 7.728 & 97 & 0.080 & & \\
\hline Total & 9.136 & 99 & & & \\
\hline
\end{tabular}

Table 6: Regression

\begin{tabular}{|c|c|c|c|c|c|}
\hline Model & B & Std. Error & Beta & t & Sig. \\
\hline Constant & 1.809 & 0.521 & - & 3.473 & 0.001 \\
\hline $\begin{array}{c}\text { Values, Norms } \\
\text { and Habits }\end{array}$ & 0.254 & 0.087 & 0.281 & 2.907 & 0.005 \\
\hline $\begin{array}{c}\text { Religious } \\
\text { needs }\end{array}$ & 0.237 & 0.109 & 0.209 & 2.160 & 0.033 \\
\hline
\end{tabular}

Based on Table 6, two elements of social capital - values, norms and habits and religious needs affect the respondents' quality of life. Each shows the Beta values of 0.28 and 0.20 . Social need elements and capabilities have shown no significant value. This analysis can also be explained by the following equation:

$\mathrm{Y}=\mathrm{a}+\beta \mathrm{X} 1+\beta \mathrm{X} 2$

$\mathrm{Y}=$ quality of life

$\mathrm{a}=$ constant

$\beta=$ regression coefficient

$\mathrm{X} 1=$ values, norms and habits

$\mathrm{X} 2=$ religious needs

Quality of life $=1.809+(0.28) *$ values, norms and habits + $(0.21)$ religious needs.

In light of the investigation directed, it was discovered that there was a positive connection between social capital and personal satisfaction. This outcome is likewise in accordance with the examination directed by $[19,8,3]$. These examinations have likewise demonstrated positive outcomes between social capital and personal satisfaction. In spite of the fact that in the discoveries of this examination, the component of social convictions has no huge impact on the personal satisfaction; it is not quite the same as the discoveries. Their examination found that there was a positive connection between the component of social trust and the personal satisfaction.

\section{Conclusion}

From this study, it can be concluded that the level of social capital and quality of life of B40 group in Kuala Terengganu is high. In order to improve the quality of life of the B40 group, social capital factors such as values, norms, habits, social rules, capabilities or personal abilities and religious needs should always be addressed to improve the quality of life of individuals. This is because the findings show that these factors can contribute to the quality of life of the respondents. In future, the study may also take into consideration other elements to be tested.

\section{Acknowledgement}

This project has been funded by the Ministry of Higher Education Malaysia via Fundamental Research Grant Scheme (FRGS / 1/2017 / SS06 / UniSZA / 01/1 / RR243). The authors would like to thank the Research Management, Innovation and Commercialization Centre, Universiti Sultan Zainal Abidin, Terengganu, Malaysia for providing the financial assistance to support the publication fee of this article.

\section{References}

[1] Lin, N. (2001). Social Capital: A Theory of Social Structure and Action, Cambridge University Press.

[2] Babaei, H., Zomorrodian, A. H., Sarjit, S. G., Nobaya, A. and Falahati, L. (2011). Social Capital and Human Development: A Meta-Analysis in Iran, Journal of American Science, 7(6): 194-197.

[3] Ounagh, N. and Ounagh, M. (2011). A Comparative Study of Social Capital and Quality of Life in Delhi and Tehran, Journal of Exclusion Studies, 1(1): 19-35.

[4] Nieboer, A., Lindenberg, S., Boomsma, A. and Van Bruggen, A. C. (2005). Dimensions of Well-Being and Their Measurement: The Spf-II Scale, Social Indicators Research, 73(3): 313-353.

[5] Jabatan Perangkaan Malaysia. (2016). Statistik Pendapatan dan Perbelanjaan Isi Rumah, https://www.dosm.gov.my/v1/index.php?r=column/ctwoByCat\&pa rent_id=119\&menu_id=amVoWU54UT10a21NWmdhMjFMMWcy Zz09

[6] Flores, M. and Rello, F. (2003). Social Capital and Poverty Lessons from Case Studies in Mexico and Central America, Culture and Agriculture, 25(1): 1-10.

[7] Yaghoubzadeh, N. (2011). Investigate the Correlation between Social Capital and Economic Development in Provinces, Australian Journal of Basic and Applied Sciences, 5(12): 3160-3163.

[8] Roslan, A., Russayani, I. and Nor Azam, A. (2010). The Impact of Social Capital on Quality of Life: Evidence from Malaysia, European Journal of Economics, Finance and Administrative Sciences, 22: 113-123.

[9] Fukuyama, F. (2002). Social Capital and Development: The Coming Agenda, SAIS Review, 12 (1): 23-37.

[10] Muhamad, F. N. (2003). Penilaian Dampak Pembangunan Ke Arah Kesejahteraan Masyarakat; Penilaian Dampak Sosial, Utusan Publication and Distributor.

[11] Norizan, A. G. (2003). Kualiti Hidup Penduduk Pulau Negeri Terengganu: Satu Kajian di Pulau Redang dan Pulau Perhentian, $\mathrm{PhD}$ thesis, Kolej Universiti Sains dan Teknologi Malaysia.

[12] Siti, F. A. R. (2006). Kriteria kualiti hidup berkeluarga, http://www.ikim.gov.my/bm/paparmedia.php?key=781.

[13] Ancok, D. (1998). Membangun Kompetensi Manusia dalam Millenium Ke-Tiga, Psikologika: Jurnal Pemikiran dan Penelitian Psikologi, 3(6): 5-17.

[14] Gittel, R. and Thompson, J. P. (2001). Making Social Capital Work: Social Capital and Community Economic Development. In S. Saegert, J. P. Thompson and M. R. Warren (Eds.), Social Capital and Poor Communities. New York: Russell Sage Foundation, pp. 115-135.

[15] Robison, L. J., Marcelo, E. S. and Schmid, A. A. (2002). Social Capital and Poverty Reduction: Toward a Mature Paradigm. Michigan State University.

[16] Mohd Shaladdin, M., Wan Abdul Aziz, W. M. A. and Nik Wan, O. (2009). Analisis Kesejahteraan Hidup Nelayan Pesisir, Jurnal Kemanusiaan, 8: 58-77.

[17] Haynes, R. (2010). The Value of R-squared in Regression (it is minor),

http://www.smartersolutions.com/blog/wordpress/2010/04/02/thevalue-of-r-squared-in-regression-it-is-minor/.

[18] Colton, J. A. and Bower, K. M. (2002). Some Msiconceptions About About $\mathbf{R}^{2}$. International Society of Six Sigma Professionals, EXTRA Ordinary Sense, 3(2): 20-22.

[19] Noghani, M., Asgharpour, A., Safa, S. and Kermani, M. (2009). Quality of Life and Social Capital in Mashhad City in Iran, Journal of Mathematics, 3(16): 1-5. 